\title{
Outlook for democracy and democratic institutions
}

\author{
Roger B. Myerson ${ }^{1}$
}

Published online: 11 January 2021

(c) National Association for Business Economics 2021

\begin{abstract}
If countries are not ready for democracy until they have a well-developed civil society, which can take many years to develop, then we need to identify its essential elements, so that their development can be directly encouraged in new democracies. It is argued here that autonomously elected local governments are the essential elements of civil society. A theory of the foundations of the state should begin by recognizing that states are established by leaders. Both to win power and to wield it, a leader needs an ability to make credible long-term promises of future rewards. For a successful democracy, we need that our democratic candidates should also have reputations for respecting democratic norms and for using public resources effectively in public service, and not just for reliably rewarding loyal supporters. Such reputations for democratic leadership can be generated most abundantly in local politics. In a federal democracy, successful local leaders can demonstrate their qualifications to compete for higher office. In this way, autonomously elected local governments effectively reduce entry barriers into national politics. It is suggested that Americans should never again elect anybody president who has not served responsibly in some lower public office under our constitutional system of government.
\end{abstract}

Keywords Civil society · Democracy $\cdot$ Federalism · Leadership

I want to consider first the question of what do we need from a theory of democratic political development. Then I will sketch how basic principles of economic analysis can give us such a theory. And finally I will try to suggest how this theoretical perspective can sharpen our insights into some issues facing America now, in 2020.

In 2003, when the American government decided to invade Iraq with a promise that the invasion would help Iraq become a democratic ally, there was a basic social-science question of "how do we do that?" The results, of course, showed that we Americans did not know how to accomplish our professed goals in taking charge of the political destinies of the people in Iraq. It was a disaster for people in Iraq, and it was costly frustration for America. And then, of course, a similar intervention had similar difficulties in Afghanistan.

A decade later, by 2013, America's leaders reached a general consensus on the opposite extreme that international

Speech delivered at the NABE Annual Meeting, October 5, 2020.

Roger B. Myerson

rmyerson@uchicago.edu

1 Harris School of Public Policy, University of Chicago, 1307 East 60th Street, Chicago, IL 60637, USA actions to support democratic political development might be impossible even for the world's most powerful superpower. And, I would argue, a result of this fear to attempt state-building has been that American military might has been almost useless in dealing with crises in Libya and Syria, for example. Another result has been an urge to wall out the world, as we have had leaders seriously arguing that we should build a wall from the Pacific Ocean to the Gulf of Mexico rather than try to do something about a breakdown of law and order in some small Central American countries, which has made people there so desperate that they are willing to go through the enormous challenges of trying to break into the USA. Our leaders have argued that we should build a wall from one sea to another across a great continent, rather than try to help restore law and order in a few small countries.

A high point in our aspirations for spreading democracy might have been around 2011, around the time of the Arab Spring. I recall an article that Yuliya Tymoshenko, a former prime minister of Ukraine, wrote in Al Jazeera in 2011. She argued that Egyptians, then in the middle of their Arab Spring, should learn from the frustrating failures of her country's experience from the 2004 Orange Revolution. Her advice in this article was that democracy is not 
made by elections alone, and that democracy needs a strong civil society to protect against leaders who might merely pretend to accept democratic norms. She warned, however, that civil society is an intricate and mysterious entity that evolves over decades, if not centuries. Yuliya Tymoshenko is not the only one to have argued these points, but in $2011 \mathrm{I}$ wrote something in response to her (Myerson 2011), and I'd like to share the main points of that response with you now.

Civil society is necessary for democracy. But if countries aren't ready for democracy until they have this thing, and if it can take a long time for it to develop, then we need to know what is it and how do we develop it? Paul Bremer, who ran U.S.-occupied Iraq for over a year, wrote a book about his year in Iraq (Bremer and McConnell 2006). In that book, he said that the stability of constitutional government depends on "these civil society institutions that protect individuals from the raw power of the state," and he listed political parties and trade unions and a free press and PTAs as being elements of civil society that might be essential. But he did not list tribes and religious groups, which in the history of Iraq had performed exactly this function of protecting individuals against the raw power of the state.

Was he right to make this distinction? What is essential for a strong civil society? And ultimately, should Iraqis and Egyptians and Ukrainians be advised that they need to have a few centuries that somehow match what England went through in some part of its medieval or early modern history before they can attempt to build a democracy?

What was going on before the United States and England had their successful democracies? How do people get started on a transition to democracy? And how can people develop what is necessary as quickly as possible? We need a theory of how strong democratic states develop. And we need to identify what is needed essentially in "civil society and democratic leadership."

A theory of the foundations of the state should begin by recognizing that states are established by leaders. Where there are still bookstores, you can find whole shelves of books about leadership. Let me tell you what I think is the essence of leadership for these state-building purposes. In many books on leadership, probably the most common definition of leadership is that the leader is like a visionary strategic planner. And, as the proverbial elephant has many aspects, so great leadership also can have many aspects, which can include visionary strategic planning; but I would suggest that it may be more like the side or the foot of an elephant, and we may need to look elsewhere to find the essential aspect (which in the elephant is of course the trunk).

States are established by recognized leaders who can motivate a network of active supporters. You need supporters to win power in any political system. And you need supporters to wield power. So I would argue that, ultimately, what a leader really needs more than anything else is a reputation for reliably rewarding good service in the long run.

First, in order to win power, you are going to have to persuade people to work for you, and you may not be in a position to give generous rewards until you get power. So before you can win power, your supporters have to believe that you will, in fact, reward them after you win power. This confidence in your promises of future rewards is one thing that you need to motivate the people who can help you to win power.

Second, to motivate the people who help you to wield power, Becker and Stigler (1974) have shown that efficient motivation involves back-loaded late-career rewards, which economists call moral-hazard rents. So the state is going to need to be able to make promises of late-career back-loaded moral-hazard rents to people who serve as responsible officials in essential agencies of the state. Thus, both to win power and to wield it, a leader needs an ability to make credible long-term promises of future rewards. And that, to $\mathrm{me}$, is the essential theory of leadership.

Alchian and Demsetz (1972) explored related ideas about the role of leadership in a theory of the firm. But agents in a firm might look to state courts for enforcement of the contracts that say that they will be paid certain rewards if they perform in certain ways. However, such reliance on the state for external enforcement of internal organizational contracts is not possible for a political faction that exists to take power in the state itself.

Given that agents in our firms look to state courts for contract enforcement, and given that contract enforcement depends on the functioning of the state, the state's political leaders are ultimately the highest guarantors of social incentive systems. Political leaders have to guarantee incentive systems within their own faction, but when their faction takes charge of the state then it will have ultimate responsibility for maintaining a system that enforces contracts for the whole society.

The state is a network of agents who could profit from abuse of their powers. And so, agents of the state, who number many thousands in a large state, must expect greater long-term rewards from good service, and those rewards are their back-loaded moral-hazard rents. Incentives for public service will be ineffective if they are not supported by political leadership. After all, promises of back-loaded rewards become a debt owed by the state, and leaders could be tempted to repudiate this debt (by alleging bad service) and then resell the office with its moral-hazard rents to a new supporter.

So political leaders must guarantee the state's proper allocation of moral-hazard rents. But then you have to ask, "Who can bind a leader who wields the sovereign power of a state?" The answer is the leader's supporters together have such a power, because, if the leader loses 
his reputation for reliably rewarding good service, then he cannot motivate people to serve him now. Under any political system, a leader who has been largely deserted by the people who helped him to carry out his will would be a leader who will soon fall from power.

My 2008 article in the American Political Science Review created a model of sequential contests for power in which the whole key was that you cannot win a contest for power without broad support. And the main result was that a contender could not recruit any supporters unless he created a court where they could depose him if they found that he had failed to appropriately reward any of them.

Such a court could be identified with the regular meetings of the leader with his chief lieutenants or courtiers. I like to use the word "courtiers." A courtier is somebody in the highest circles of power who is an agent of the state, but who also spends a lot of time near the leader of the government, and who regularly gossips with others there about their leader.

The point is that courtiers must jointly judge their leader even as they serve him. Our theory of political leadership is that, in any kind of political system, a leader must maintain a reputation for reliably rewarding good service. To maintain that reputation, the leader must bring his senior lieutenants together regularly. And in all these meetings with senior officials of the state, while they may talk about major changes of state policy or administrative personnel, the implicit number-one article of business is that the leader must make sure that everybody trusts that he is going to maintain his reputation for reliably rewarding their service. If the leader unfairly dismisses a senior lieutenant, or brings in somebody over the head of someone who deserved promotion, or does not give a promotion when someone has earned it, then the leader has to justify his actions to his courtiers or he will lose their confidence. Then the standards of behavior that a leader must maintain to keep his supporters' trust become a fundamental political law or a personal constitution for him.

In any political system, any leader's personal constitution must include reliably rewarding good service, but it may also include other norms. For example, a leader's expressions of impiety that violate society's norms might also be something that would shock people and cause them to lose trust in their leader.

I want to argue that this story can help us to understand how formal constitutions are enforced. A leader may fear to violate a formal constitution when his personal relationships with supporters were developed in the context of this formal constitution. A supreme political leader typically has had a long career. You don't rise to the heights of power when you're 20 years old, starting out your career; you do it when you've been around a few decades. And, if your personal relationships in your political career were all developed in the context of serving under the country's formal constitution, then if you suddenly started violating that constitution late in your career, it could shock the supporters on whom you have relied to gain the heights of power, causing them to question your future reliability.

A democratic state needs candidates with reputations for respecting democracy. That is, voters need to have some confidence that their candidates will accept the outcome of elections and will not use violence or unfair extra-legal means to intimidate opponents. (Yuliya Tymoshenko remarked that such reliable democratic leadership was hard to identify in Ukraine's Orange Revolution.)

For successful democracy, we need that our democratic candidates should also have reputations for using public resources for public service, and not just for rewarding loyal supporters. Under any political system, a leader is going to have to do something to make sure that his loyal supporters feel that they gained something for having been part of the team. But democracy will function successfully only if, in the competition for votes, we have candidates who have a reputation for actually using public power to serve the interests of the voters at large.

But we could have a pathology where democracy fails to generate any benefits for the public if the voters would not reject a corrupt incumbent because they do not expect better from anybody else. That is, the voters might not reject a corrupt government leader if they would not expect better from any alternative candidates. Thus, democratic development depends on an ample supply of leaders who have reputations for using public resources to serve the public, and not just to provide lucrative patronage jobs for their inner circle.

So now we have established that successful democratization will require a supply of leaders who have a reputation for working within the rules of the democratic system and also for using power effectively to serve the public. But this supply might not exist in a country that has never had a functioning democracy in the past, and then successful democratization will depend on having as many opportunities as possible for individuals to start developing such good reputations for democratic public service.

Such reputations for democratic leadership can be generated most abundantly in local politics. So now, what we need to recognize in American history is the vital role of federal decentralization. Federal decentralization has created abundant opportunities for politicians to develop good democratic reputations in state and local politics.

For a variety of reasons, many people in economics and political science tend to get a little starry eyed about federalism, and I confess to being one of them. One common argument for federalism is that devolving power to local government brings it closer to the people. But that could be true also in Balkanization, that is, in having a lot of small countries. The essential point about federalism is that it means that a large country can have both a higher level of 
national government and a lower level of local governments for smaller districts within the country, and so politicians' careers can move up a ladder of democratic advancement from local government to national government.

In a federal democracy, voters elect people to local office and elect people to national office. And somebody who has held local office and has done a good job in it can be promoted by the voters to a higher office. In any organization, the ability to promote people is really important. You ask individuals to prove themselves in positions of lower responsibility, and then you promote them to higher levels depending on their performance. The power to do so is the key to controlling the organization.

For voters to truly control a democracy, they need to control a ladder of democratic advancement. In this way, autonomously elected local governments effectively reduce entry barriers into national politics. That is, to take a standard idea from economic theory and apply it in political theory, I want to say democratic subnational governments reduce barriers against entry into national politics, because successful local leaders can demonstrate their qualifications to compete for higher office in a federal democracy.

In my 2006 paper in the Quarterly Journal of Political Science, I analyzed a model of provincial and national democracy where the parameters are such that, at each level of government, if that level existed alone then there could be bad equilibria where voters would just re-elect the current incumbent, no matter what, because they believe nobody else would govern any better. But if you put these provincial and national democracies together in a federal system, where a provincial leader who serves the public well could become a strong candidate for national leadership, then suddenly the worst equilibria disappear.

Essentially, the bad equilibria would be caused by voters having low expectations about the credibility of any candidate's promise to provide better public service. In such a trap of low expectations, who would have the motive and opportunity to raise low expectations? In a unitary state where voters have low expectations (and therefore continue to re-elect the incumbent because they do not expect better from anybody else), the incumbent national leader would have no incentive to raise expectations. Indeed, the incumbent national leader would be the prime beneficiary of the voters' low expectations.

Then out-of-power candidates would like to raise their hands and say, "Elect me, and I will give you good government." But maybe that is just what the corrupt incumbent national leader said before he rose to power (think of Belarus, for example), and so the voters may understand that such statements are just cheap talk. There is no costly demonstration that out-of-power candidates can offer to prove the sincerity of their desire to use public power to serve the people.
But when there are responsible autonomous local governments, then the leaders of these local governments have real opportunities to serve the public better than the public expected. By taking advantage of these opportunities, they can show the public that they are serious about proving that their ability to provide better public service. That is, elected officials in responsible autonomous local governments can have both motive and opportunity to raise voters' expectations by providing better public service, and then democracy can start to benefit the voters.

Shortly after the American Revolution, the idea of democratic representative government was applied in France, but democracy went wrong in the French Revolution. In brief, as de Toqueville noted, the French Revolution was fought both against aristocracy and against local government. It tended to centralize power even as it was ending hereditary privileges.

So the distinction I would emphasize between the American Revolution and the French Revolution is that the American Revolution was federal. Local governments are a threat to the incumbent national leaders. Centralization lets the incumbent national leaders allocate moral-hazard rents of local government to their supporters. And so, in a centralized regime, it can be costly for a national leader to disappoint supporters who hope to be appointed to mayor or governor by suddenly saying, "Let's allow local elections."

On the other hand, federal democracy is also stable once it is established, as the history of the United States proves. Once you have a federal democracy, elected governors and mayors become key local supporters for national politicians. Kenya introduced autonomously elected provincial governments in 2013 (after what was basically a revolution in 2010). The law that introduced this reform promised to give $15 \%$ of the public budget to these new local governments. But as soon as the new provincial governors were elected, they got together, and they were so powerful that they were able to re-negotiate the formula and get $32 \%$ of the public budget.

The point is that recognized limits of local and national authority can become fundamental to the state. That line is almost directly out of Lincoln's 1860 Cooper Union Address, which was a pivotal expression of key ideas in American political philosophy. Everybody in America understands that our welfare depends on maintaining an appropriate balance between our state governments and our federal government. When Obamacare was introduced, the Democratic leadership was very careful in crafting the Obamacare provisions to make sure that they had a role for the states, because (yes) it was an increase in power to the federal government, but everybody in America knows that we want to maintain an appropriate balance between federal and state authority.

In my visits to Ukraine, I found educated people who understood the theory of democracy in very well, even 
though there was no history of democratic government in Ukraine before 1991, but who were quite puzzled about why people should worry about having an appropriate balance of power between their elected local governments and their elected national government. In Ukraine, the elected national government has had almost all the power, and so I was suggesting that the balance was completely wrong. But people there could reasonably ask, why should that matter, since officials at both levels were popularly elected.

But Americans understood, even before the American Revolution, that their welfare depended both on being subjects of the extended British empire (then the upper level of government) and also on having provincial assemblies with a significant degree of local power (at the lower level of government). And that is why the American Revolution was fought, to defend a federal balance of authority. Then after a brief interregnum, the Articles of Confederation were replaced by a Constitution that recreated a balanced distribution of power between our national government and our provincial (now state) governments.

So I want to argue that autonomously elected local governments are the key essential elements of civil society. If you have lots of nice PTAs and trade unions but without autonomously elected local governments, then it is not going to work. But when the national political system allocates a substantial share of local authority to autonomously elected local governments, then the other elements of civil society will follow.

From this perspective, we can see one important way that premature democracy could do harm. When national leaders are elected in a country before the establishment of effective democratic local governments, then the newly elected national leaders would be in a strong position to resist any future development of autonomous local democracy, so that they can centralize power in their own hands. In both Ukraine and Egypt there were genuine competitive elections for national authority. And then the elected national authorities had every incentive to prevent a devolution of power to autonomously elected local governments, and they did so.

I have argued here that democratic government may perform poorly unless it has some multi-level federal distribution of power. So we may ask, between federalism and democracy, which is more important to development? I think this is a good question, and I am not prepared to offer a final answer. The People's Republic of China is certainly not a multi-party democracy, but it could be considered a federal system in the sense that substantial powers and responsibilities have been systematically devolved to local party committees. The United Arab Emirates is also not a multiparty democracy, but it certainly has a federal distribution of power between the union level and the individual emirate level. And both China and the UAE are widely regarded as well-governed countries, which could be taken as evidence that maybe federalism might be more important than democracy for successful development.

I would argue emphatically, however, that the cultivation of democratic leadership in local politics as well as national politics can be essential in democratic state-building. And so a successful state-building intervention should be managed by a team of local political coordinators who are in touch with local politicians as well as national politicians.

In this regard, I would note that Iraq has twice been administered by foreign state-building teams, once by the British after World War 1, and then by the American-led coalition in 2003. In World War 1, Britain went in with about 70 local political coordinators who immediately ran things and set up a kingdom that lasted for 38 years. But in 2003 , it took America many months just to get a team of 18 local coordinators placed in the provinces of Iraq. Violent insurgencies took root during these months of misdirection.

I have argued that Americans' appreciation of their vital interest in maintaining an appropriate line between local and federal authority is the defining key to America's greatness (Myerson 2015). Federalism makes America rich in public offices where politicians can develop reputations for accepting constitutional limits and democratic accountability in public service. Before 2016, Americans never elected a president who had no prior record of exercising public power within legal and constitutional limits, and the exception is our current president. If I could get the attention of everybody in the United States for five minutes, I would say, let's never, ever again elect anybody who has not served responsibly in some lower public office under our constitutional system of government. Supporters of our current president could have suggested that, like Ronald Reagan, he could have run for governor of a state and served at that level for four years before running for president, so that, before elevating him to the most powerful office in the land, we could have had some demonstration of his willingness to serve within the constraints of our democratic constitutional system. ${ }^{1}$ It is essential for a successful democracy to have leaders with a long-term career commitment to working within the Constitution.

From the perspective of the theory that I've just outlined, I would note today that, in the COVID-19 crisis, the current president has used a strategy of yielding responsibility to the states. It could have been good for federalism that he was willing to delegate power in this way; but instead, he has encouraged popular resentment against state governors' policies, undermining the states. Furthermore, one of the

\footnotetext{
${ }^{1}$ I would say the same thing about other candidates in both parties, this year including Andrew Yang and Tom Steyer, who have campaigned for president without first serving in some other responsible public office.
} 
biggest problems facing the USA today is that state budgets have been absolutely overwhelmed by the COVID-19 crisis and depression. The federal government, however, can still borrow at low interest rates. At one point, the current president was reported to be asking his legal advisors about the possibility of cutting off federal aid to Democrat-run cities. The threat of partisanship in federal transfers and questions about the federal government's help in relieving these strained state budgets should have been some of the most important issues in our country this year, even if they were not the biggest on the nightly news.

But I must stop here, as I am almost out of time, with just a few minutes for questions before our network connection is scheduled to be cut off.

\section{References}

Alchian, Armen A., and Harold Demsetz. 1972. Production, information costs, and economic organization. American Economic Review 62: 777-795.

Becker, Gary, and George Stigler. 1974. Law enforcement, malfeasance, and compensation of enforcers. Journal of Legal Studies 3: $1-18$.

Bremer, L. Paul., and Malcolm McConnell. 2006. My year in Iraq: The struggle to build a future of hope. New York: Threshold Editions.

Myerson, Roger B. 2006. Federalism and incentives for success of democracy. Quarterly Journal of Political Science 1: 3-23.

Myerson, Roger B. 2008. The autocrat's credibility problem and foundations of the constitutional state. American Political Science Review 102 (1): 125-139.

Myerson, Roger B. 2011. What Egypt can learn from Ukraine. https:// econciv.wordpress.com/2011/02/18/what-egypt-can-learn-fromukraine/.

Myerson, Roger B. 2015. The strength of American federal democracy. World Bank Policy Research Paper 7512. http://home.uchicago. edu/ rmyerson/research/amerfed.pdf.
Tymoshenko, Yuliya. 2011. My revolution betrayed. https://www.aljaz eera.com/opinions/2011/2/10/my-revolution-betrayed/.

Publisher's Note Springer Nature remains neutral with regard to jurisdictional claims in published maps and institutional affiliations.

Roger B. Myerson is the David L. Pearson Distinguished Service Professor of Global Conflict Studies in the Harris School of Public Policy and the Griffin Department of Economics at the University of Chicago. Myerson has made seminal contributions to the fields of economics and political science. In game theory, he introduced refinements of Nash's equilibrium concept, and he developed techniques to characterize the effects of communication among rational agents who have different information. His analysis of incentive constraints in economic communication introduced several fundamental concepts that are now widely used in economic analysis, including the revelation principle and the revenue-equivalence theorem in auctions and bargaining. Myerson has also applied game theoretic tools to political science, analyzing how political incentives can be affected by different electoral systems and constitutional structures. Myerson is the author of Game Theory: Analysis of Conflict (1991) and Probability Models for Economic Decisions (2005). He also has published numerous articles in professional journals, including Econometrica, Journal of Economic Theory, Games and Economic Behavior, American Political Science Review, Mathematics of Operations Research, and International Journal of Game Theory. He has served as president of the Game Theory Society (2012-2014), president of the Econometric Society (2009), and vice president of the American Academy of Arts and Sciences (1999-2002). Myerson has a PhD from Harvard University and taught for 25 years in the Kellogg School of Management at Northwestern University before coming to the University of Chicago in 2001. He is a member of the American Academy of Arts and Sciences, the National Academy of Sciences, and the Council on Foreign Relations. He has received several honorary degrees, and he received the Jean-Jacques Laffont Prize in 2009. He was awarded the 2007 Nobel Memorial Prize in Economic Sciences in recognition of his contributions to mechanism design theory, which analyzes rules for coordinating economic agents efficiently when they have different information and difficulty trusting each other. 